\title{
Brasil: para um federalismo equânime e uma agenda para o municipalismo
}

\section{Cristovão Brito \& Romilda Assunção Souza}

\section{Introdução}

A criação de municípios no Brasil é um fenômeno político e administrativo que já surgiu com a empresa colonial portuguesa, mas sua gênese é romana durante a fase da República - 509 a 27 aC. Este modelo de município, suficiente para cumprir as funções de domínio colonial durante o expansionismo romano foi implantado em todas as províncias romanas, inclusive em Portugal, de onde foi transferido para o Brasil e perdurou até o fim do Império na administração da vida local nas Vilas. Desde este período esta antiga forma institucional de administração da vida local passou por transformações, resultando no ordenamento constitucional vigente.

Devido o forte protagonismo dos governos das Capitanias (Colônia), depois as províncias (Império) e por último os estados (República), as Vilas com suas Câmaras municipais (o equivalente dos municípios à época) tinham pouco prestígio até a promulgação da $7^{\text {a }}$ Constituição brasileira. Somente na Constituição Federal de 1988 (CF/1988) que o município foi investido de autonomia política, administrativa e financeira e competências, mesmo que ainda pouco claras.

É no contexto político, jurídico e administrativo da vigência da CF/1946 que o fenômeno político da criação de municípios no Brasil emergiu de maneira pronunciada em 1962,quando foram criados de uma só vez 1.187 municípios; houve um refluxo durante a fase da ditadura militar, quando somente foram criados 38 novos municípios entre 1970 e 1980; e com a redemocratização que culminou com a promulgação da CF/1988 foram criados mais 500 novos municípios entre 1989 e 1991; e entre 1991 e 2010 foram criados mais 1.074 novos municípios, passando o país a ter atualmente 5.565 municípios. No estado da Bahia, de 1989 até o presente momento foram criados 50 municípios.

Em quase todos os casos de emancipação de distritos, seja na Bahia ou noutros estados brasileiros, a principal motivação para a criação de novos municípios é a administrativa, mas que não está só, ela é potencializada pelas motivações econômica, política e geográfica. Assim, a população empobrecida e abandonada em seus distritos distantes das cidades (da sede municipal), busca superar as graves dificuldades de atendimento de suas demandas sociais cotidianas: infraestrutura, serviços públicos, saneamento, abastecimento, educação, comunicação, saúde, lazer, trabalho, habitação etc. por meio do recurso previsto na CF/1988 - a separação do municípiomatriz e a criação de um novo município. Este caminho, em certos casos, nem sempre é a decisão

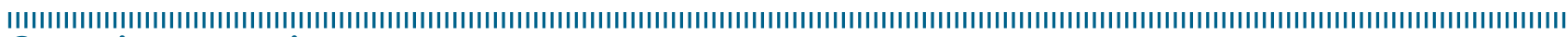
Como citar este artigo:

BRITO, Cristóvão \& SOUZA, Romilda Assunção. "Brasil: para um federalismo equanime e uma agenda para o municipalismo”. In: RÜCKERT, A. A.; SILVA, A. C. P. da; SILVA, G. de V. (Orgs.). Geografia Política, Geopolítica e Gestão do Território: integração sul-americana e regiões periféricas. Porto Alegre: Editora Letra1, 2018, p. 177-195 DOI 10.21507/9788563800367-11 
mais acertada, mas diante das circunstâncias é o que se tem para o momento.

Considerando que as motivações para a criação de novos municípios são variadas e as condições objetivas são amplas, a quantidade de municípios no Brasil, e em especial no estado da Bahia, só não é maior por causa da publicação da Emenda Constitucional (EC) No 15, de 1996, pelo Congresso Nacional, a qual proíbe a criação de novos municípios no Brasil até a aprovação de nova lei com critérios bem mais rígidos.

Assim, para tentar entender o que se manifesta como coerente nos processos de criação de municípios na Bahia busca-se avaliar alguns elementos próprios do funcionamento dos municípios: competências, fontes de recursos e responsabilidades, o contexto no qual se insere (federalismo) e a noção de descentralização política do Estado brasileiro envolvendo o município definido pela CF/1988 e suas implicações sociespaciais.

Essencialmente a noção de "desenvolvimento", que não necessariamente significa "desenvolvimento econômico", permeia o fato político e administrativo da criação de um novo município. Com isso, o objetivo é compreender e explicar: a) em que condições é possível se corroborar o intento da criação de novos municípios? b) quais as principais condições que entram na contabilidade dos sujeitos interessados pela criação de novos municípios? c) até que ponto o "pacto federativo" como está definido respeita a ideia de equidade econômica e políticoadministrativa para evitar a reprodução cada vez ampliada das desigualdades socioespaciais no país?

\section{Elementos para a compreensão do federalismo e da descentralização política do Estado no Brasil contemporâneo}

Tem-se por acertada a decisão de o legislador decidir peladescentralização política do Estado brasileiro consagrada na $\mathrm{CF} / 1988$, reconstruindo desta maneira, os princípios federalistas de autonomia e de competências dos respectivos entes federados, desfigurados pela constituição de 1967, a qual foi outorgada pela ditadura militar no Brasil (de 1964 a 1985), praticamente transformando o Estado Federado num Estado Unitário, com decisões centralizadas.

Ao longo de 21 anos de forte centralização e de tensão política,era de se esperar que o legislador constituinte, em boa parte imbuído de interesse progressista, tentasse, dentro do possível, estabelecer no texto constitucional, condições radicalmente contrárias à experiência política e administrativa implantada à força pelos governos militares, que por meio de um golpe de Estado tomaram o poder no Brasil.

Mesmo com posições claramente conservadoras do governo Sarney (1985-1989) que sucedeu os militares e de sua base política consolidada no Congresso Nacional Constituinte ( $\mathrm{CNC}$ ) aninhada no que pejorativamente foi alcunhada de "centrão" à época, com cerca de $40 \%$ dos parlamentares, é que Almeida, M., (2005, p. 32) afirma: “[...] o apoio à descentralização era mais amplo e incluía as forças políticas mais importantes, tivessem ou não relação com interesses subnacionais. Democracia com descentralização era uma ideia-força e como tal tinha gravitação própria". Assim, como resultado da influência direta dos governadores dos estados sobre suas bancadas parlamentares no CNC em defesa dos interesses estaduais (principalmente maior participação nas rendas nacionais), bem como com a pressão exercida pelos prefeitos e pela Associação Brasileira de Município foi conferido também aos municípios o status de ente federado e maior participação nas rendas nacionais.

A consolidação dos acordos entre os interesses divergentes durante o processo constituinte quanto à autonomia municipal implicaria a substituição de relações verticais, determinadas pela União Federal, desde a República Velha (FONSECA, 2006), por relações “quase horizontais"garantidas textualmente pelas transferências de fundos financeiros intergovernamentais, definição de encargos e de competências atribuídas a cada um dos entes federados, em que pese tais competências (Artigos 23, 24, 29 e 30 da CF/1988) ainda serem um tanto confusas. 
Entretanto, certas diretrizes normativas muito avançadas,como a ideia republicana da autonomia do poder local, desde que foi criada em 1988, enfrenta reações diante da realidade política brasileira secularizada na tradição oligárquica e centralizadora, que por força de inércia tem erigido obstáculos ao desenvolvimento esperado da vida municipal compartilhada na unidade federativa.

Na realidade o que se observa é um resquício de temor e desconfiança de até onde se pode chegar com a possibilidade da descentralização política do Estado nacional,indicada atual Lei maior do país. Considerando isso, as forças conservadoras nacional/regional sempre encontram adeptos que, de alguma maneira, resistem à ideia mais larga da descentralização política do Estado, quando elaboram e implementam políticas sociais (transferência direta de renda, como no caso do programa do Governo federal - Bolsa Família entre outros), com o objetivo de atender aos cidadãos mais necessitados, no município. No fim, em que pese o benefício chegar aos mais necessitados, esta ação é capturada pelo interesse eleitoral subjacente das forças políticas no mando federal ou estadual, o que implica o reforço do controle político sobre os recursos da União federal e um pouco menos das unidades da federação.

Em decorrência disso, o desejo idealizado da superação das grandes discrepâncias sociais, econômicas e espaciais nacionais continuará postergado e, não raro aparece como um clichê convenientemente apresentado pelas autoridades federais ou estaduais em momentos oportunos.

O Gráfico 1 ilustra uma das dimensões socioespaciais associadas ao forte desequilíbrio que prevalece no pacto federativo, no qual muitas unidades da federação e nelas os Municípios, sobretudo nas regiões menos desenvolvidas (Nordeste e Norte), a maior parte da população permanece sob condições de pobreza intensa e acesso precário a serviços sociais coletivos como: saneamento, saúde e educação, sem falar do baixíssimo padrão de vida.

Em meio à desconfiança quanto aos possíveis resultados da descentralização política do Estado federado é mantida, de um lado, a persistente centralização política na escala federal baseada na capacidade arrecadadora da União federal, em que pese sua dissimulação, e do outro lado, o predomínio de uma prática extremamente nociva à democracia e a qualquer pretensão de superação do status quo, a imposição da vontade pessoal dos "chefes políticos" regionais e locais manifesta no "municipalismo autárquico" (ABRUCIO, 2006) confirmando sua intenção personalista e desconsiderando a unidade federativa e as demandas dos cidadãos.

O modelo de Estado federalista definido com a instauração da República brasileira pressupõe a descentralização política, mas de difícil equalização dos interesses entre os distintos entes federados e entre as forças políticas que lhes dão sentido e existência. Daí resulta pouca margem para a coordenação adequada dos interesses de competição e de cooperação, sobressaindo o primeiro (ABRUCIO, 2006). Isto implica forçosamente fortes contrates socioespaciais entre regiões, estados e municípios. A descentralização política, o compartilhamento de recursos e a clareza na definição de competências e encargos tornamse quase inconciliáveis quando o contexto político interescalar do poder não está desenvolvido o suficiente para enfrentar com segurança os problemas que envolvem princípios subjacentes à tradição oligárquica e à tradição republicana.

Assim, subjacente ao peso da herança oligárquica, na prática, os recursos econômicos garantidos pela CF/1988 são mantidos politicamente em condições de certa escassez na medida em que o governo da União federal, mediante acordos no Congresso Nacional consegue ampliar sua capacidade arrecadadora com base nas contribuições sociais, e não nos tributos, para compensar as perdas dos recursos tributários arrecadados pela União federal,e de sua obrigação das transferências constitucionais para os Estados e para os Municípios como explica Almeida, (2005):

Em 1985, o Fundo de Participação dos Estados (FPE) e o Fundo de Participação dos Municípios (FPM) chegavam respectivamente a $14 \%$ e $16 \%$ das receitas federais provenientes de impostos. Em 1993, eles 
Gráfico 1. Brasil: índice de pobreza multidimensional por grandes regiões e unidades da federação - 2002, 2007,2012 e 2013.

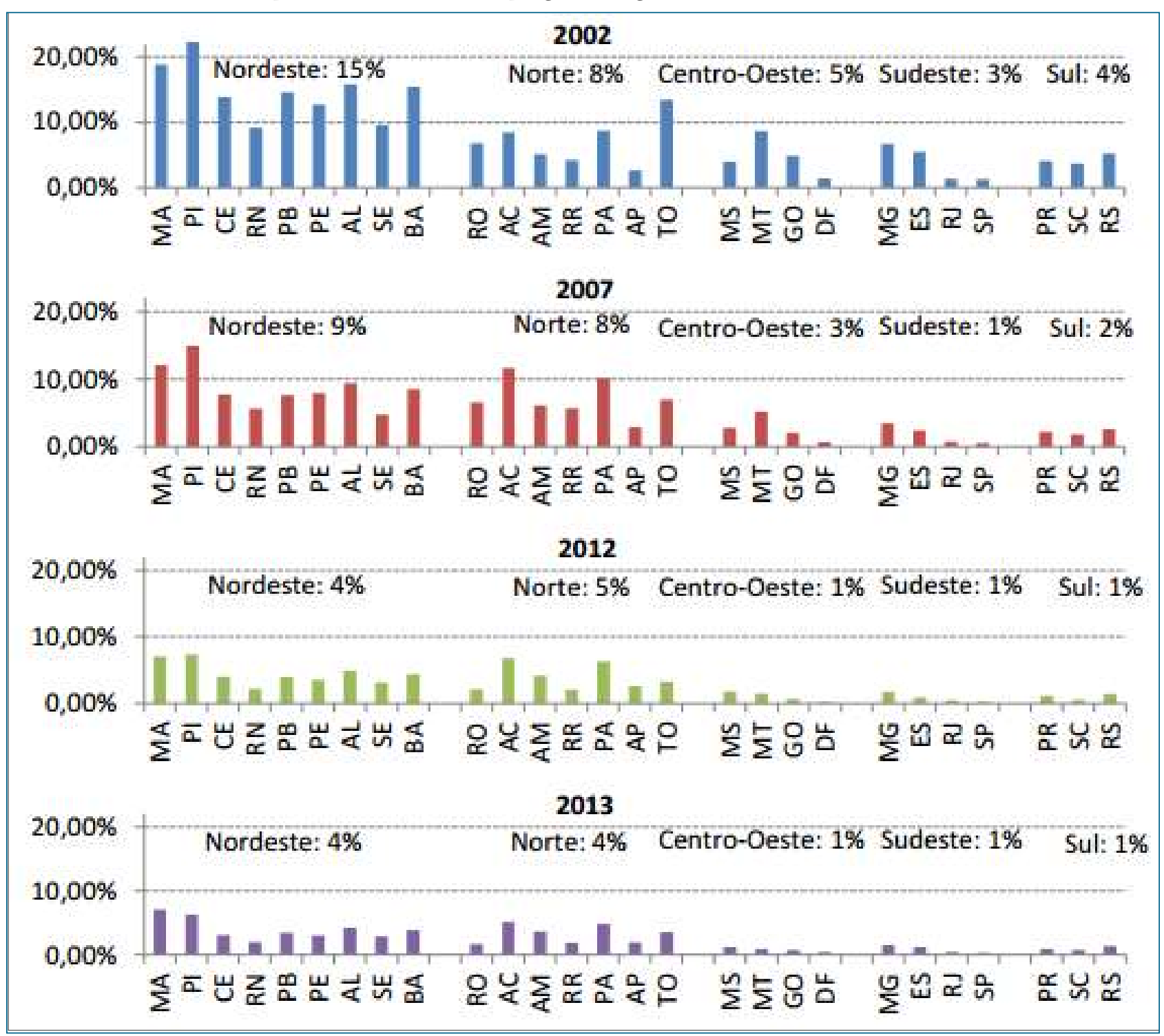

Fonte: FAHEL, Murilo; TELES, Letícia; CAMINHAS, Davy, 2015: 18.

atingiram $21,5 \%$ e $22,5 \%$. Ademais, $10 \%$ do Imposto sobre Produtos Industrializados (IPI) foi destinado a um fundo de compensação para os estados que deixaram de taxar suas exportações de manufaturados e $3 \%$ do Imposto de Renda e do IPI foram alocados em um fundo de desenvolvimento regional, que deveria apoiar projetos no Norte, Nordeste e Centro-Oeste do país. (ALMEIDA, 2005, p. 32).

Assim, em 1994 o Governo federal criou um mecanismo fiscal - Fundo Social de Emergência (FSE), em 2000 foi renomeado de Desvinculação das Receitas da União (DRU) -, o qual “[...] permite que o governo aplique os recursos destinados a áreas como educação, saúde e previdência social em qualquer despesa considerada prioritária e na formação de superávit primário. A DRU também possibilita o manejo de recursos para o pagamento de juros da dívida pública". (BRASIL, 2016a).

Uma vez que por força de lei não é possível reduzir os percentuais dos recursos de impostos arrecadados pela União federal, em razão das transferências constitucionais intergovernamentais (Fundo de Participação dos Municípios (FPM) e do Fundo de Participação dos Estados (FPE), a engenharia fiscal proporcionada pela DRU resultou num acréscimo médio anual 
de quase $85 \%$ sobre os recursos provindos das receitas de contribuições em favor da União federal. Mas tudo isso com a anuência de todos os partidos políticos, dos respectivos governadores e de suas bancadas no Congresso Nacional, assim como os prefeitos que não reagem (Gráfico 2) ${ }^{1}$.

A DRU tem sido sistematicamente renovada pelos mandatários do Governo federal. Em 2015 foi renovada até 2023, com a majoração de $20 \%$ para $30 \%$ sobre as desvinculações das receitas de contribuições. (BRASIL, SENADO FEDERAL, 2016).

Nas últimas duas décadas a União federal criou uma capacidade de arrecadação anual média robusta, em torno de $21 \%$ do Produto Interno Bruto (PIB), e repassa aos Estados e Municípios, em média 3,6\% por ano, ficando com $17,7 \%$, dos quais pode usar livremente $20 \%^{2}$. A série estatística histórica entre 1997 e 2015 é ilustrativa (Tabela 1).

Esta escassez de recursos em favor dos entes subnacionais é antiga, Fonseca (2006, p. 94) afirma que na fase imperial "A falta de recursos

|| |||||||||||||||||||||||||||||||||||||

1 Fernando Henrique Cardoso (FHC) foi ministro da fazenda no governo do presidente Itamar Franco (1993 a 1994), quando a equipe econômica propôs o plano de estabilização econômica (Plano Real), o país estava imerso em um longo período de altas taxas de inflação desde a "crise do milagre econômico", em fins dos anos 1970. FHC foi eleito para o primeiro mandato (19951998) por uma coligação de centro-direita liderada pelo Partido da Social Democracia Brasileira (PSDB) junto com o Partido da Frente Liberal (PFL) e o Partido da Mobilização Democrática (PMDB), entre outros. Logo, com ampla maioria de deputados e senadores no Congresso Nacional; e em seguida foi reeleito para 1999 a 2002. Tido como oposição, o seu sucessor, o presidente Luis Inácio Lula da Silva (Lula) foi eleito para o primeiro mandato (2003-1998) numa coligação de centro esquerda, liderada pelo Partido dos Trabalhadores (PT) junto com o Partido Liberal (PL), o PMDB, o Partido Comunista do Brasil (PC do B), o Partido Socialista Brasileiro (PSB), entre outros; também foi reeleito para um segundo mandato consecutivo (2007-2010) e elegeu o seu sucessor, a presidente Dilma Rousseff, com uma coligação ampliada mais à direita, que também foi reeleita para o mandato seguinte. Os governos Lula e Dilma mantiveram os princípios do governo de FHC e não alteraram as relações do pacto federativo. Mantiveram os governos subnacionais submetidos à escassez dos recursos de receitas tributárias, enquanto o Governo federal nadava na abundância das receitas de contribuições, fora da obrigação da partilha com o FPE e o FPM.

2 De 1994 até 2015 o Governo poderia usar livremente 20\%, aumentado para 30\% de 20116 até 2023. nos municípios aumentava ainda mais a sua fragilidade com relação às províncias e ao governo central, pois no contexto da renda nacional, o império dispunha de $80,88 \%$, as províncias $16,7 \%$, e os municípios 2,5\%". Ainda segundo Fonseca (2006, p. 95), "[...] outro aspecto prejudicial para o governo local foi a ausência, na Constituição de 1891 , de regras quanto às rendas municipais, uma vez que no contexto da arrecadação total de impostos, o percentual da União era de 63\%, dos Estados 28\%, e dos municípios, 9\%."

Além disso, a definição de responsabilidades e competências não é tão clara, implicando concorrência de competências entre os três entes federados, favorecendo as incertezas quanto às responsabilidades institucionais referentes ao atendimento das demandas essenciais dos cidadãos, bem como sua qualidade, uma vez que os três entes federados podem oferecer os mesmos serviços.

A CF/1988 foi concebida com ambição ampla quanto aos objetivos e duração temporal,o "Art. 24" define que "Compete à União, aos Estados e ao Distrito Federal legislar concorrentemente sobre:". Neste caso, a União federal assume por escolha própria, baseada na antiga tradição centralizadora, quase todas as competências com uma racionalidade de Estado unitário, deixando as sobras, inclusive econômicas para os demais entes federados subnacionais. Isso implica precariedade da coordenação da vida nacional e ampliação da competição desigual entre as instâncias de Governo federadas; implica também privilégios da União federal dirigidos para certas unidades da federação ou municípios,segundo as conveniências, com prejuízo para todos, sobretudo quanto à ampliação das desigualdades socioeconômicas e espaciais regionais ${ }^{3}$.

Sem a clara definição de responsabilidades e competências e sem a equidade das receitas partilhadas, e pior, sob uma coordenação precária e parcial do pacto federativo e submetidos à "guerra fiscal", resta então aos cidadãos, em seus municípios, a escassez e a precariedade da

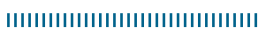

3 A capacidade de arrecadação não é igual entre os estados membros, e menos ainda entre os municípios. 
Gráfico 2. Brasil: Resultado primário das receitas do Governo Central (\% do PIB em R\$ milhões) - 1997 a 2015.

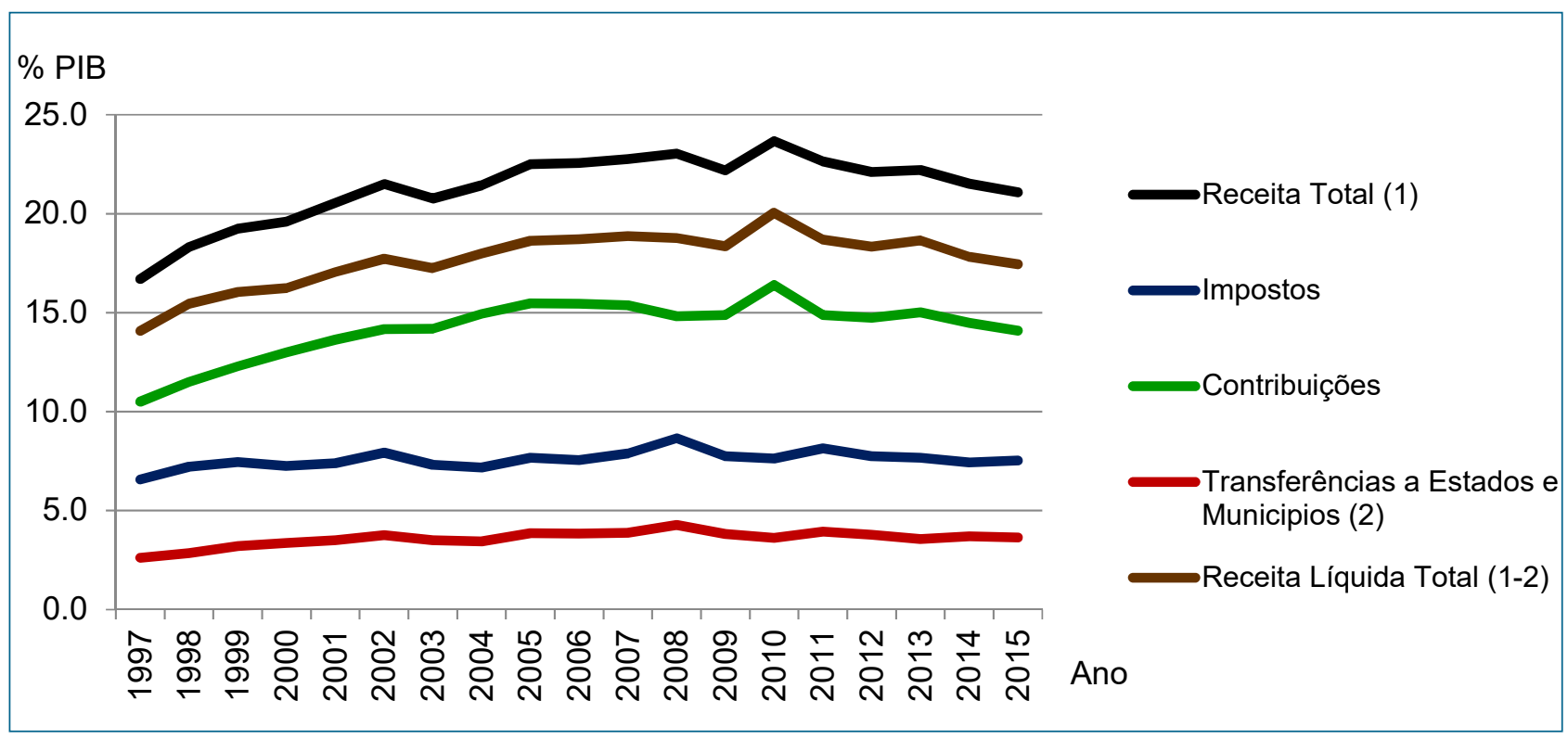

Fonte: Elaboração própria, com dados coletados em: Brasil, 2016c.

Tabela 1. Brasil: Resultado primário das receitas do Governo Central - 1997 a 2015.

\begin{tabular}{lccccc}
\hline \multirow{2}{*}{ Receitas } & \multicolumn{5}{c}{ \% do PIB (R\$ milhões a preços correntes) } \\
\cline { 2 - 6 } & $\mathbf{1 9 9 7}$ & $\mathbf{2 0 0 0}$ & $\mathbf{2 0 0 5}$ & $\mathbf{2 0 1 0}$ & $\mathbf{2 0 1 5}$ \\
\hline Receita Total (1) & 16,7 & 19,6 & 22,5 & 23,7 & 21,1 \\
Impostos & 6,6 & 7,3 & 7,7 & 7,6 & 7,5 \\
Contribuições & 10,5 & 13,0 & 15,5 & 16,4 & 14,1 \\
Transferências a Estados e Municípios (2) & 2,6 & 3,4 & 3,9 & 3,6 & 3,6 \\
Receita Líquida Total (1-2) & 14,1 & 16,2 & 18,6 & 20,0 & 17,4 \\
\hline
\end{tabular}

Fonte: Elaboração própria, com dados coletados em: Brasil, 2016c.

oferta de serviços coletivos. O problema não é pior porque a maioria dos municípios assume despesas de responsabilidade da União e dos Estados, como destaca Bremaeker (2013) em pesquisa recente sobre os municípios baianos:

Os 9 Municípios com população entre 2 mil e 5 mil habitantes têm um gasto com as despesas de responsabilidade do Estado e da União 4,26 vezes maior que o da sua arrecadação tributária. Para os 61 Municípios com população entre 5 mil e 10 mil habitantes esta relação é de 3,52 vezes. Para os 178 Municípios com população entre $10 \mathrm{mil}$ e 20 mil habitantes esta relação é de 2,92 vezes. E o pior é que estes serviços são relativamente mais caros para os Municípios de menor porte demográfico. (BREMAEKER, 2013, p. 5).
Segundo uma regra universal popular, os problemas poderão ficar ainda piores, se,no caso do "pacto federativo" for incluída a "guerra fiscal", como é o caso do Brasil. A "guerra fiscal” já foi um instrumento de planejamento e intervenção econômica-regional utilizado pelo Governo federal desde os anos 1960, como maneira de direcionar investimentos econômicos para regiões economicamente deprimidas, a exemplo das subvenções para a industrialização das regiões Nordeste, Norte, Centro-Oeste e Sul (CASTRO, 1975). A partir dos anos 1990, por falta de uma política fiscal equitativa para toda a federação (VARSANO, 1997; DULCI, 2002) a União federal lançou a maioria dos Estados e os Municípios, os que podem, numa competição desesperada por investimentos econômicos, sobretudo 
privados, oferecendo em contrapartida, renúncia fiscal e benefícios creditícios, sem garantias de durabilidade dos possíveis investimentos. (BRITO, 2010; OLIVEIRA, I., 2012; NERY, 2016) ${ }^{4}$.

Neste contexto destaca Scheinowitz (1993):

[...] os recursos atribuídos a cada região, ou comunidade são, de certa maneira, o teste da solidariedade nacional. Uma região, uma comunidade descentralizada, um estado da federação não pode viver como um pária socieconômico da nação, sem que esta situação dê lugar a profundas mágoas e, às vezes, movimentos secessionistas da parte do desfavorecido ou mesmo do rico que se sente ameaçado. (SCHEINOWITZ, 1993, p. 51).

Destarte, o federalismo brasileiro, com viés de centralização política velada, mesmo sob regime democrático consolidado,está envolto por uma forte assimetria,deveras prejudicial aos entes subnacionais, especialmente em relação aos municípios que possuem capacidade arrecadadora menor e menos eficiente, o que certamente implica sérios percalços à possibilidade de desenvolvimento socioespacial.

Contrariamente ao caminho trilhado pelo Brasil, outros países organizados em Estado unitário a exemplo da Espanha ${ }^{5}$ (RAMIÓ; SALVADOR, 2006), da França e da Grã-Bretanha (ABRUCIO, 2006), da Itália, da Bélgica e de Portugal dentre outros (SCHEINOWITZ, 1993) estão cada vez mais próximos da descentralização política de maneira mais efetiva, reconhecendo direitos e autonomia para unidades "subnacionais" com os fins mais diversos, a exemplo do que sugere SCHEINOWITZ (1993, p. 15): “Uma melhor repartição dos poderes entre o Estado e as coletividades descentralizadas traria também uma maior eficiência na utilização

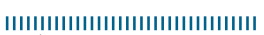

4 É o caso das fábricas de calçados instaladas, na região Nordeste, atraídas dos estados de São Paulo e do Rio Grande do Sul por meio da "guerra fiscal". Assim, a possibilidade de desenvolvimento socioespacial (SOUZA, M., 2004), ou que implique a emancipação das pessoas (SEN, 2000) fica muito distante; pois a promessa é apenas de gerar emprego, precário, ao nível do "fordismo periférico", e renda com salários baixos. Assim, a ideia de desenvolvimento permanece como um "mito", como defende Furtado. (1981).

5 Refere-se aqui à representação de Estado para a comunidade internacional, em que pese se saber das questões fundamentais de afirmação de identidades nacionais de cada "país", como no caso da Espanha, da Bélgica e da França. (JACINT, 2006). dos recursos públicos e, de maneira geral, na realização dos objetivos econômicos e culturais".

\section{Descentralização/centralização do Estado e o processo de criação de municípios no Brasil}

O interesse sobre a criação de municípios no Brasil não é novo (MELLO, 1971; BRASILEIRO, 1973), ganhou grande visibilidade entre 1961 e 1963 quando foram criados de uma só vez 1.548 municípios, dos quais foram extintos 447 entre 1964 e 1965, e no último ano foram criados mais 31 municípios. (BREMAEKER, 1991). Ao longo de seis décadas, desde 1960 até 2012, foram criados 2.805 novos municípios, alternando-se entre períodos de relativa descentralização (até 1964), centralização (de 1964 até 1985) e outra vez promessa de descentralização política - a partir de 1985.

Desde a CF/1946 até a de 1967, os Municípios gozavam de autonomia política, financeira e administrativa; exceto os das capitais dos estados, os antigos territórios federais e os que possuíam estâncias hidrominerais, nestes, o prefeito era nomeado pelos governadores dos respectivos estados com o assentimento do presidente da República.

Essa autonomia conferida aos municípios era apenas formal e muito limitada, em virtude da forte centralização política e financeira advinda, sobretudo da reforma tributária e fiscal de 1966, e da CF/1967. A tutela das outras instâncias de Governo sobre os Municípios se exprimia também pelo fato de as municipalidades ficarem na dependência quase exclusiva dos repasses da União e dos Estados, e de uma parcela considerável desses repasses estar vinculada a gastos exclusivos já previstos no orçamento municipal.

$\mathrm{Na}$ CF/1946 buscando equacionar as disparidades regionais do Brasil à época, os legisladores adicionaram ao Art. 15 a Emenda Constitucional N. 5 de 1961, que passou a ter a seguinte redação:

$\S 4^{\circ}$ A União entregará aos municípios $10 \%$ (dez por cento) do total que arrecadar do imposto de que trata o $n^{\circ}$ 
II, efetuada a distribuição em partes iguais, e fazendo-se o pagamento, de modo integral, de uma só vez, a cada município, durante o quarto trimestre de cada ano. $\S 5^{\circ}$ A União entregará igualmente aos municípios $15 \%$ (quinze por cento) do total que arrecadar do imposto de que trata o $\mathrm{n}^{\circ} \mathrm{IV}$, feita a distribuição em partes iguais, devendo o pagamento a cada município ser feito integralmente, de uma só vez, durante o terceiro trimestre de cada ano.

$\S 6^{\circ}$ Metade, pelo menos, da importância entregue aos municípios, por efeito do disposto no parágrafo $5^{\circ}$, será aplicada em benefícios de ordem rural. Para os efeitos deste parágrafo, entende-se por benefício de ordem rural todo o serviço que for instalado ou obra que for realizada com o objetivo de melhoria das condições econômicas, sociais, sanitárias ou culturais das populações das zonas rurais. (BRASIL, 1961, p. 1).

Com a nova redação foi modificado o Parágrafo $4^{\circ}$ e foram introduzidos outros, entre os quais, o Parágrafo $5^{\circ}$ que preconizava mudanças essenciais, ao possibilitar o aumento de $5 \%$ na participação das receitas totais líquidas do Imposto de Renda, além do crédito de $10 \%$ do Imposto sobre Circulação de Mercadorias (ICM). Com isso, entre 1961 e 1964, ocorreu um "surto de emancipação municipal", quando surgiram casos escandalosos de muitos municípios criados apenas como um simulacro. (MELLO, 1971).

Esses episódios traduziam a defesa de interesses não confessados de políticos desatentos com o interesse público, e governadores de estados que intentavam tão somente angariar mais verbas para o estado sob sua administração, diante da possibilidade de aumentar a participação nas transferências intergovernamentais, já que as quotas eram distribuídas equitativamente entre todos os municípios brasileiros com a vigência da Emenda Constitucional No 5, de 1961.

Pós-1964 imediatamente tornaram-se nulas muitas das emancipações municipais (MELLO, 1971) e uma nova legislação passou a disciplinar a criação de novos municípios. Mello (1971) destaca que com a vigência da $C F / 1967$, regulamentada pela Lei Complementar $N^{\circ} 1$, de 9 de novembro do mesmo ano, a criação de novos municípios era matéria exclusiva dos parlamentos estaduais, que inclusive decretavam Leis Orgânicas únicas aplicadas indistintamente a todos os municípios, com o estabelecimento de critérios mínimos e únicos para a autorização de criação de novos municípios no Brasil. Assim determinava o texto da Lei:

Art. $1^{\circ}$ - A criação de Município depende de lei estadual que será precedida de comprovação dos requisitos estabelecidos nesta Lei e de consulta às populações interessadas.

Parágrafo único - O processo de criação de Município terá início mediante representação dirigida à Assembleia Legislativa, assinada, no mínimo, por 100 (cem) eleitores, residentes ou domiciliados na área que se deseja desmembrar, com as respectivas firmas reconhecidas.

Art. $2^{\circ}$ - Nenhum Município será criado sem a verificação da existência, na respectiva área territorial, dos seguintes requisitos:

I - população estimada, superior a 10.000 (dez mil) habitantes ou não inferior a 5 (cinco) milésimos da existente no Estado;

II - eleitorado não inferior a 10\% (dez por cento) da população;

III - centro urbano já constituído, com número de casas superior a 200 (duzentas);

IV - arrecadação, no último exercício, de 5 (cinco) milésimos da receita estadual de impostos (BRASIL, 1967).

O estabelecimento de condições mínimas para a criação de novos municípios num contexto político centralizador e autoritário colocou freio nos casos exagerados de criação municípios, mas não deu solução às demandas locais da população, o que não impediu a criação de novos municípios com a emancipação de localidades com suas respectivas população, economia, cultura etc., denominadas por Tomio (2005) de "estoques de áreas emancipáveis"6. Muitas localidades conseguiram atender a Lei, confirmando a tese de Tomio (2005), com centenas de novos municípios no Brasil, como revelam os estudos de Brito (2004), Oliveira, M., (2009), Almeida, K., (2013) e Souza, R., (2015) para o estado da Bahia.

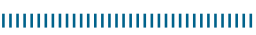

6 Estoques de áreas emancipáveis correspondem às grandes extensões de terras municipais onde vive uma parte relativamente numerosa da população municipal, normalmente nas jurisdições de distritos muito distantes da sede municipal (as cidades), mas que não recebem atenção adequada da prefeitura. 
A pesquisa desses autores indicou que a emancipação dos distritos dos respectivos municípios-matriz, em que pese os possíveis prejuízos que tenha gerado inicialmente com a perda de parte de recursos das transferências intergovernamentais, revelou-se uma solução definitiva para problemas intangíveis, diante dos recursos limitados para o município-matriz, uma vez que este não precisará mais arcar com as demandas sociais e de infraestrutura custosas dos ex-distritos.

A condição de pauperismo da maior parte das populações interioranas, mal atendidas em suas demandas por serviços públicos essenciais e "encerradas" em seus distritos semiabandonados pelas autoridades públicas locais, despertam nessas populações o desejo de almejar qualquer iniciativa que as aproximem de condições de vida mais vantajosas, a exemplo do que se encontra disponível para as comunidades que habitam as sedes dos municípios, tais como: o acesso aos serviços de saúde e de educação, saneamento, abastecimento de água e alimentar, estradas, dentre outros.

\section{O processo recente de criação de municípios na Bahia após-1988}

Em 1960 o estado da Bahia com $567.295 \mathrm{~km}^{2}$ de superfície tinha apenas 194 municípios, onde vivam quase seis milhões de habitantes;como resultado da Emenda Constitucional N. 5 de 1961, em 1963passou a ter 336 municípios, registrando um aumento de 142 novas unidades. Mesmo com o regime exceção pós-1964 nenhum dos municípios criados anteriormente perdeu seu status; ao contrário, foram criados mais 31 municípios até 1988.Após a promulgação da Constituição do Estado da Bahia de 1989 foram criados mais 48 municípios, atingindo 415 unidades, já com cerca de 12 milhões de habitantes, e em 2000 foram criados mais dois municípios totalizando 417 (Tabela 2) ${ }^{7}$. Mas ainda há 136 processos

|||||||||||||||||||||||||||||||||||||

7 Segundo o IBGE (2011), em 1960 o Brasil tinha 2.766 municípios, em 1970 passou ater 3.953, em 1980 eram 3.991, em 1991 foi
Tabela 2. Bahia: quantidade de municípios e população (milhões de habitantes) - 1960/2010.

\begin{tabular}{lcccccc}
\hline Ano & $\mathbf{1 9 6 0}$ & $\mathbf{1 9 7 0}$ & $\mathbf{1 9 8 0}$ & $\mathbf{1 9 9 1}$ & $\mathbf{2 0 0 0}$ & $\mathbf{2 0 1 0}$ \\
\hline Municípios & 194 & 336 & 336 & 415 & 417 & 417 \\
População & 5,9 & 7,5 & 9,5 & 11,9 & 13,1 & 14,0 \\
\hline
\end{tabular}

Fonte: Elaboração própria, com dados coletados em: Brasil, 2011.

de emancipação de distritos tramitando na Assembleia Legislativa da Bahia (ALBA), dos quais menos de 10 têm chance de proveito, segundo os novos critérios para a criação da nova lei em tramitação no Congresso Nacional ${ }^{8}$.

Segundo o que foi definido na CF/1988, a Lei Complementar Estadual (LCE) No 2 de 1990, do estado da Bahia prevê o seguinte:

Art. $3^{\circ}$ - O procedimento iniciar-se-á mediante requerimentos do Deputado, instruído com representação, subscrita por, no mínimo dez por cento dos eleitores residentes e domiciliados nas áreas interessadas, com as respectivas firmas reconhecidas.

Art. $4^{\circ}$ - Nenhum Município será criado sem a verificação da existência, na respectiva área territorial, dos requisitos mínimos de continuidade territorial, unidade históricocultural do ambiente urbano e consulta plebiscitária favorável, previstos na Constituição da República e, ainda, os aqui estabelecidos:

I - população estimada não inferior a 8.000 (oito mil) habitantes;

II - centro urbano já constituído, com população estimada não inferior a 1.000 (hum mil) habitantes, com pelo menos duzentos prédios e, dentre estes os que possam abrigar os serviços Municipais;

III - eleitorado correspondente a, no mínimo, vinte por cento da população;

IV - arrecadação, nos dois últimos exercícios, de impostos estaduais, por habitantes não inferior a quatro décimos da média per capita alcançada pelo Estado no mesmo

||IIIIIIIIIIIIIIIIIIIIIIIIIIIIIIIII

ampliado para 4.491, em 2000 já eram 5.507 municípios e em 2010 ampliou para 5.565 municípios.

8 O novo Projeto de Lei do Senado, (199/2015), aprovado em $15 / 07 / 2015$, dentre outros critérios estabelece que para a criação de um município, quanto ao número de habitantes este deverá ter: 6 mil nas regiões Norte e Centro-Oeste, 12 mil na região Nordeste e 20 mil nas regiões Sudeste e Sul. 
período, excluído do cálculo os dados correspondentes à Região Metropolitana do Salvador;

V - informação sobre as condições sócio-econômicas da área a ser desmembrada e do município de origem a ser auferida pela Comissão de Divisão Territorial da Assembleia Legislativa, com o deslocamento de seus membros às localidades interessadas (BAHIA, 1990).

Tem-se por princípio, conforme a nova Lei, que exceto três municípios: Apuarema (7.647 habitantes), Feira da Mata (6.643 habitantes) e Lagedo do Tabocal (6.476 habitantes) que não possuíam população total de 8.000 habitantes no ano de criação (1989), e mais nove municípios que atendiam este critério, mas não tinham ainda mil habitantes na sede municipal, mas no recenseamento de 2010 este critério já tinha sido ultrapassado, todos os outros municípios seguiram a sua prescrição (Tabela 3 ).

Isso reforça a ideia da existência de "estoques de áreas emancipáveis". O que certamente não fugiu à regra dos demais municípios criados em todo o Brasil,com grande extensão dos municípios-matriz e contingente demográfico relativamente grande, submetido à precariedade da oferta de bens e serviços e o "isolamento" da população local em virtude da dificuldade do serviço de transporte e comunicações à época.

Acredita-se que os principais motivos que induzem a mobilização política dos distintos agentes sociais que se interessam pela emancipação dos distritos municipais estão vinculados a múltiplas causas desenvolvidas simultaneamente.

Os fatores até então identificados sistematicamente, e que juntos motivam a busca pela autonomia política das áreas emancipáveis vinculam-se aos de ordem política, administrativa, econômica dinâmica, e econômica por estagnação, conforme identificaram Bremaeker (1993), Noronha (1997), Cigolini (1999), Brito (2004), Oliveira, M., (2009), Almeida, K., (2013) e Souza, R., (2015) ao estudarem os processos de criação de municípios nos estados do Rio de Janeiro, Paraná e Bahia.

As motivações políticas são subjacentes a todos os processos de criação de novos municípios, tendo em vista que desfrutar do prestígio político e social do cargo de prefeito e/ ou de vereador é algo sempre bem visto para as lideranças políticas locais, que ao vislumbrarem a possibilidade de serem eles próprios os ocupantes da posição de mando localmente partem para o empreendimento. Outra fonte de motivação política para a criação de municípios é a existência de rivalidades entre as lideranças políticas locais; estes buscam solucionar suas demandas com o apoio de políticos com mandato na Assembleia Legislativa, que possam assumir a posição de patrono das lideranças políticas locais e, com isso, assumir a defesa da emancipação das área sem litígio. Por sua vez, o deputado certamente contará com o reconhecimento político de seu esforço eseu nome ou o de quem ele indicar,no momento das eleições estaduais,poderá ser lembrado pela população que foi ajudada, confirmando a sua futura base eleitoral.

Acredita-se que, por um certo período de tempo, as novas lideranças que ascendem junto com o novo município, por um mecanismo de defesa e ao mesmo tempo de obrigação, passam a gravitar em torno do seu "padrinho político" que, segundo a importância do novo município e diante da posição do "padrinho político" no sistema de forças regionais nas Assembleias Legislativas e no executivo estadual, poderá suprir-lhe importantes demandas, até que um novo grupo político venha substituir o anterior.

As causas de ordem administrativa permitem elaborar um forte apelo social por parte das lideranças interessadas na emancipação de distritos municipais, pois há na verdade uma imbricação de difícil superação entre o descaso das administrações dos municípios-matriz, que realizam a maior parte dos investimentos na sede municipal, enquanto os demais distritos são entregues ao abandono, sobretudo em municípios de grande extensão superficial. Tal fato implica investimentos custosos em estradas e sua manutenção periódica, transporte público, oferta de água tratada e esgotamento sanitário, escolas (professores e demais servidores), postos de saúde e equipe médica, e demais unidades administrativas para atender as demandas dos 
Tabela 3. Bahia: municípios criados 1989.

\begin{tabular}{|c|c|c|c|c|c|c|}
\hline \multirow{2}{*}{ Municípios } & \multicolumn{2}{|c|}{ População 1991} & \multicolumn{2}{|c|}{ População 2010} & \multirow{2}{*}{ Área } & \multirow{2}{*}{ Município-matriz } \\
\hline & Na sede & Total & Na sede & Total & & \\
\hline Serra do Ramalho & 2.159 & 33.164 & 6.274 & 31.638 & $2.593,4$ & Bom Jesus da Lapa \\
\hline Sobradinho & 19.482 & 21.207 & 20.002 & 22.000 & $1.238,9$ & Juazeiro \\
\hline Itabela & 13.577 & 20.848 & 48.485 & 61.631 & $2.343,5$ & Porto Seguro \\
\hline Presidente Tancredo Neves & 5.542 & 18.531 & 9.569 & 23.846 & 417,2 & Valença \\
\hline Itaguaçu da Bahia & 1.530 & 17.341 & 2.598 & 13.209 & $4.451,2$ & Xique-Xique \\
\hline Ponto Novo & 5.542 & 17.171 & 8.405 & 15.742 & 497,3 & $\begin{array}{c}\text { Santa Maria da } \\
\text { Vitória }\end{array}$ \\
\hline Andorinha & 3.447 & 17.170 & 5.862 & 14.414 & $1.247,6$ & Senhor do Bonfim \\
\hline Caraíbas & 518 & 17.088 & 2.088 & 10.222 & 805,6 & Tremendal \\
\hline Jucuruçu & 1.299 & 16.012 & 2.292 & 10.290 & $1.398,8$ & Itamarajú \\
\hline Cabaceiras do Paraguaçu & 923 & 14.523 & 3.101 & 17.327 & 226,0 & Muritiba \\
\hline São José do Jacuipe & 3.633 & 14.100 & 3.488 & 10.180 & 406,0 & Capim Grosso \\
\hline Quixabeira & 2.710 & 13.927 & 3.663 & 9.554 & 387,7 & Serrolândia \\
\hline Piraí do Norte & 1.848 & 13.759 & 3.689 & 9.799 & 187,3 & Ituberá \\
\hline Mulungu do Morro & 4.931 & 13.741 & 4.075 & 12.249 & 566,0 & Morro do Chapéu \\
\hline Adustina & 2.279 & 13.714 & 5.572 & 15.702 & 632,1 & Paripiranga \\
\hline Igrapiúna & 955 & 12.895 & 3.746 & 13.343 & 527,2 & Camamu \\
\hline Ourolândia & 2.356 & 12.235 & 6.341 & 16.425 & $1.487,7$ & Jacobina \\
\hline Sítio do Quinto & 2.147 & 12.050 & 5.172 & 12.592 & 702,1 & Jeremoabo \\
\hline São Félix do Coribe & 6.764 & 11.916 & 10.587 & 13.048 & 949,4 & $\begin{array}{c}\text { Santa Maria da } \\
\text { Vitória }\end{array}$ \\
\hline Umburanas & 3.661 & 11.540 & 6.320 & 17.000 & $1.670,5$ & Campo formoso \\
\hline Varzedo & 1.536 & 11.540 & 3.149 & 9.109 & 226,8 & $\begin{array}{l}\text { Santo Antônio de } \\
\text { Jesus }\end{array}$ \\
\hline Banzaê & 939 & 11.489 & 4.402 & 11.814 & 227,2 & Ribeira do Pombal \\
\hline Bonito & 4.349 & 11.085 & 6.232 & 14.834 & 726,6 & Morro do Chapéu \\
\hline Novo Triunfo & 2.398 & 11.080 & 7.503 & 15.051 & 251,4 & Antas \\
\hline Lagoa Real & 1.148 & 10.978 & 2.808 & 13.934 & 877,4 & Caitité \\
\hline Ribeirão do Largo & 1.266 & 10.930 & 2.693 & 8.602 & $1.271,3$ & Encruzilhada \\
\hline Iuiu & 4.227 & 10.841 & 5.284 & 10.900 & $1.485,8$ & Malhada \\
\hline Caetanos & 891 & 10.655 & 2.734 & 13.639 & 774,7 & Poções \\
\hline Nova Ibiá & 2.358 & 10.502 & 2.807 & 6.648 & 178,7 & Gandu \\
\hline Nova Fátima & 3.462 & 10.445 & 5.074 & 7.602 & 349,9 & Riachão do Jacuipe \\
\hline Nova Redenção & 3.581 & 10.318 & 5.237 & 8.034 & 431,3 & Andaraí \\
\hline São Domingos & 3.442 & 10.276 & 4.607 & 9.226 & 326,9 & Valente \\
\hline Bom Jesus da Serra & 1.127 & 10.226 & 2.495 & 10.113 & 421,5 & Poções \\
\hline Novo Horizonte & 751 & 10.184 & 2.511 & 10.673 & 609,2 & Ibitiara \\
\hline Itatim & 6.254 & 10.039 & 10.112 & 14.522 & 583,4 & Santa Terezinha \\
\hline Caturama & 1.192 & 9.714 & 2.374 & 8.843 & 664,6 & Botuporã \\
\hline Madre de Deus & 8.792 & 9.183 & 16.854 & 17.376 & 32,2 & Salvador \\
\hline Matina & 1.389 & 8.999 & 3.473 & 11.145 & 775,7 & Riacho de Santana \\
\hline Araçás & 3.759 & 8.940 & 5.807 & 11.561 & 487,1 & Alagoinhas \\
\hline Vereda & 961 & 8.914 & 1.379 & 6.800 & 874,2 & Prado \\
\hline São José da Vitória & 5.217 & 8.768 & 5.162 & 5.715 & 72,5 & Buararema \\
\hline Sítio do Mato & 4.257 & 8.699 & 5.107 & 12.050 & $1.751,0$ & Bom Jesus da Lapa \\
\hline Muquém do São Francisco & 807 & 8.257 & 1.283 & 10.272 & $3.638,1$ & Barra \\
\hline Mirante & 496 & 8.189 & 1.809 & 10.507 & $1.061,0$ & Poções \\
\hline Saubara & 5.469 & 8.016 & 7.584 & 11.201 & 158,0 & Santo Amaro \\
\hline Apurema & 7.159 & 7.647 & 5.117 & 7.459 & 154,9 & Jaguaquara \\
\hline Feira da Mata & 1.470 & 6.643 & 2.366 & 6.184 & $1.668,5$ & Carinhanha \\
\hline Lagedo do Tabocal & 3.291 & 6.476 & 5.149 & 8.305 & 431,9 & Maracás \\
\hline
\end{tabular}

Fonte: Elaboração própria, com dados coletados em: Bahia, 1995; Brasil, 2010; 1991. 
cidadãos, os da sede e os dos demais distritos próximos e distantes.

Como os recursos financeiros à disposição dos municípios são escassos, as prefeituras tendem a negligenciar o atendimento das necessidades da população em distritos distantes, inclusive pela perspectiva de se "perder" os investimentos realizado sem decorrência da uma possível emancipação destes distritos. Assim, os distritos, sobretudo os mais distantes da sede do município, são negligenciados pela prefeitura, favorecendo, com o tempo, a possibilidade da emancipação municipal, que sendo possível, o novo município terá acesso direto aos recursos de transferências intergovernamentais obrigatórios e voluntários, e também de sua própria economia. A possibilidade da emancipação das "áreas emancipáveis" implica a atenção dos sujeitos interessados na manutenção do status quo ao tempo que sempre "atende" as demandas da população do novo município.

As causas de ordem administrativa nem sempre são óbvias, em decorrência de a iniciativa do projeto de emancipação ter origem nos grupos dirigentes e somente depois é que chega ao povo para a mobilização social. Isso, em certa medida, depende dos acordos firmados entres os agentes em esferas políticas superiores.

Em que pese serem legítimos os argumentos baseados na proximidade da oferta de serviços públicos à população, o que é uma realidade, sua admissão para o processo de autonomia municipal, em muitos casos, fica sempre como promessa, até porque alguns tipos de demandas de saúde, como os mais frequentes - são bastante dinâmicos, social e temporalmente. Com isso, a construção de um pequeno hospital e/ou de uma pequena maternidade e a manutenção de uma equipe médica adequada, bem como os respectivos aparelhos e equipamentos, nem sempre é possível realizar, independente de o município ser novo ou antigo.

Para ilustrar essa situação, têm-se os exemplos de municípios no Recôncavo Baiano: Conceição da Feira, que no ano de 2010 tinha população total de 20.391 habitantes e PIB municipal em 2014 estimado em $\mathrm{R} \$ 194,267$ milhões, ainda não possuía um pequeno hospital; no mesmo período, o município de São Félix, com população de 14.098 habitantes e um produto municipal estimado em $\mathrm{R} \$ 144,011$ milhões, já possui o seu hospital desde 1950. Vale dizer que ambos são municípios mais antigos e que também são vizinhos de outros municípios que possuem hospitais.

Um exemplo de municípios de emancipação recente é Dias d'Ávila (emancipado em 1985). No ano de 2010 o município possuía 66.440 habitantes e o PIB municipal estimado em 2014 foi de $\mathrm{R} \$ 3.122,830$ milhões, mantém um hospital e maternidade públicos, bem como várias policlínicas particulares. Araçás (emancipado em 1989) com população de 11.561 pessoas e PIB estimado de $\mathrm{R} \$ 358,482$ milhões já tinha um posto de saúde e uma pequena maternidade desde 1996, em 2003 o serviço de saúde foi ampliado com um hospital; além disso, desde fins dos anos 1990 implantou e assumiu o ensino escolar médio, atualmente integra a rede de ensino do governo do estado 9 .

Esses exemplos servem para demonstrar que o fato da simples proximidade do poder público em relação aos cidadãos, no caso das municipalidades, não assegura a garantia do pronto atendimento de algumas demandas da população local. Essa situação ocorre por interferências diversas, que provocam a postergação dos investimentos públicos, seja porque tal empreendimento não faz parte do projeto político-administrativo do governante, seja por motivos de insuficiência orçamentária,também falta de interesse e/ou por malversação do dinheiro público.

Entre as motivações econômicas, há as de ordem dinâmica e as associadas à estagnação e declínio econômico (NORONHA, 1997). As de ordem dinâmica são condicionantes fortes para incentivar o processo de criação de municípios. A possibilidade de contar com receitas consistentes e previsíveis, provenientes de taxas e impostos do setor industrial, e de um setor comercial e



9 A partir da publicação da Emenda Constitucional No 14, de 1996, os municípios atuarão prioritariamente no ensino fundamental e na educação infantil; como não há impedimento, o ensino médio pode ser oferecido também pelo município. 
de serviços numeroso e importante, de jazidas minerais de alto valor econômico, bem como da atividade agropecuária etc., existentes nos limites de distritos municipais, principalmente os distantes da sede municipal, motiva algumas lideranças políticas locais a tentar ocupar diretamente a função de prefeito. Contudo, isso demanda negociações e apoios políticos externos, no âmbito da esfera política estadual.

Alguns dos municípios emancipados no Recôncavo Baiano entre 1962 e 1989 conseguem um desempenho razoável de sua economia, implicando um importante incremento em suas receitas próprias, é o caso dos seguintes municípios: Lauro de Freitas (comércio e indústria); Simões Filho (possui um grande distrito industrial baseado na siderurgia, química, metalurgia etc.); Madre de Deus (possui um terminal marítimo petroleiro); Araçás (possui vários campos produtivos de petróleo e gás); Dias d'Ávila (corresponde à extensão industrial do Polo Industrial de Camaçari, onde se destaca a metalurgia do cobre e a química), estes são os principais ${ }^{10}$. Mas há os municípios emancipados em 1962 que outrora eram economicamente dinâmicos em termos regionais, como é o caso de Teodoro Sampaio, Terra Nova e Amélia Rodrigues, cada um tinha uma grande usina de açúcar, mas desde os anos 2000 estão desativadas e a economia dos municípios está estagnada.

Há ainda razões que, por seu caráter negativo, também concorrem de maneira significativa para que ocorram emancipações municipais. Essas emancipações resultam da estagnação econômica do município e, por esta razão, os distritos distantes da sede municipal não são assistidos, permitindo uma situação de marginalização da população desses distritos, cujas lideranças políticas buscam reverter essa condição por meio da emancipação municipal.

Desta maneira o processo de emancipação se desenvolve tal qual os apresentados

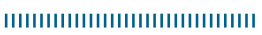

10 Lauro de Freitas, Simões Filho e Madre de Deus foram emancipados de Salvador, os dois primeiros em 1962, terceiro em 1989; Dias d’Ávila foi emancipado de Camaçari em 1985. anteriormente, porém o novo município fica inteiramente na dependência das transferências intergovernamentais, principalmente do FPM, já que a circulação da riqueza é elementar e as transferências estaduais são tão menos importantes quanto menores forem as possibilidades de geração e de circulação da riqueza localmente.

A título de exemplo, para a criação do município de Saubara, o critério demográfico,a estagnação econômica, o descaso da prefeitura de Santo Amaro para com o distrito, a grande distância entre a sede municipal e a sede do distrito certamente motivaram a iniciativa política local para empreender o processo de emancipação ${ }^{11}$.

Criado em 1990 com uma população total de 8.016 habitantes e destes, 5.469 residindo na área urbana (em 1991), o município desmembrado de Santo Amaro localiza-se no fundo da Bahia de Todos os Santos, uma espécie de "fim de linha”, que não dá acesso, por terra, a outras localidades. A base econômica do município é o comércio popular para a população local, a pesca artesanal e o "turismo de excursão de 1 dia" para a população pobre dos municípios vizinhos ${ }^{12}$. Essa desvantagem, bem como os custos elevados dos investimentos sociais no antigo distrito talvez tenha sido importante para sua emancipação políticado município-matriz.

Assim, quanto maior a realização de receita da sua própria economia, maior é a independência em relação às transferências intergovernamentais para os investimentos da prefeitura. Mas para que haja uma proporção razoável de recursos próprios em relação às receitas de transferências intergovernamentais é necessário a convergência de múltiplas condições. Assim, a existência de fontes consistentes de reprodução da economia local, como a existência de atividades econômicas relativamente robustas e duradouras, bem como o intercâmbio de mercadorias, tecnologias e capital, e eficiência na política tributária local,

\section{IIIIIIIIIIIIIIIIIIIIIIIIIIIIIIIIIII}

11 A distância entre a cidade de Saubara e Santo Amaro é $33 \mathrm{~km}$. Saubara foi criado em 1989, mas a estrada de rodagem foi construída somente em 1995, pelo Governo do estado, e asfaltada em 2000. 12 BRITO; RAMOS (2016) discutem a pobreza e o turismo de excursão no município de Saubara. 
dentre outras são fundamentais ${ }^{13}$. Estas condições se desenvolvem historicamente e de maneira seletiva no espaço geográfico, segundo a lógica do desenvolvimento desigual e combinado do capitalismo. (TROTSKY, 1977; SMITH, 1988).

\section{Para além do legislado: elementos que possibilitam ou impedem a criação de novos municípios na Bahia}

Nesta parte, abordam-se os fatos que para além da legislação, possibilitam ou impedem a criação de novos municípios na Bahia no período pós1988. Para isso discute-se no mesmo movimento do processo de criação de municípios em 1989 na Bahia, os exemplos de dois municípios criados, Apuarema e Saubara, e dois distritos, Abrantes e Stela Dubois ${ }^{\mathbf{1 4}}$, que não conseguiram a emancipação apesar de à época atenderem as condições exigidas pela lei.

Como já indicado, os processos de emancipação política de municípios no Brasil ocorre simultaneamente por várias motivações essenciais: administrativas, econômicas e políticas. No caso dos municípios de Apuarema e Saubara ficou explicito nos levantamentos de campo que a falta de assistência por parte da prefeitura de Jaguaquara/Wenceslau Guimarães ${ }^{15}$ e de Santo Amaro, respectivamente, bem como estagnação econômica e a ausência de serviços públicos como saúde, educação, infraestrutura, saneamento básico, segurança e assistência

|IIIIIIIIIIIIIIIIIIIIIIIIIIIIIIIIIII

13 GOMES; MAC DOWELL (2000) apresentam uma análise acurada sobre os recursos de transferências intergovernamentais e próprios à disposição dos municípios, bem como o tamanho demográfico. Os autores desenvolvem uma argumentação pessimista quanto à criação de novos municípios, e concluem que municípios pequenos e pobres são inviáveis e atrapalham os municípios grandes e dinâmicos, sobretudo os da região Sudeste, com destaque para o estado de São Paulo. A ambição dos autores foi explicar a criação de municípios no Brasil, mas fundamentaram a pesquisa somente em estatísticas fiscais e demográficas, tendo como referência apenas o ano de 1996. Os autores desconsideram qualquer possibilidade de superação da determinação estatística. 14 Abrantes é distrito do município de Camaçari, e Stela Dubois é distrito de Jaguaquara.

15 O município de Apuarema foi constituído com partes do município de Jaguaquara e de Wenceslau Guimarães. social à população foram os principais motivos que levaram as lideranças políticas e a população local a se mobilizarem pela emancipação política das referidas localidades em 1989.

Para a comunidade local, o sucesso da emancipação política abriria as portas para a solução de suas demandas diretamente com as fontes de recursos advindas das transferências intergovernamentais e de sua própria economia, em que pese ser diminuta, mas seria gerida diretamente pelo novo município.

Os requisitos legais para a criação de municípios devem ser atendidos (tabela 4), mas não determinam as regras do jogo político, estas são conjunturais. Quando ocorrem conflitos de interesses a solução emerge da capacidade de mediação e das estratégias que os sujeitos ou grupos de políticos utilizam para superar os conflitos de acordo com seus interesses.

Para Tomio (2002), a possibilidade da emancipação das "áreas emancipáveis" parece não ser algo decidido de maneira simples, exclusivamente com base na lei; há outras mediações, pois depende quase exclusivamente da interação política entre o executivo e o legislativo estadual. O autor argumenta que:

A institucionalização/alteração da regulamentação e o sentido desta (facilitar/dificultar as emancipações) dependerão da interação entre executivo e legislativo estadual e do tamanho/consistência da coalizão de governo existente no legislativo estadual (constituída pelos resultados eleitorais ou por alianças políticas posteriores): (a) quando for minoritária, a lei promulgada tenderia a facilitar as emancipações (comparada ao status quo); (b) quando for majoritária, com apoio vigoroso, o sentido da lei dependeria do interesse do executivo em facilitar/dificultar as emancipações; (c) quando for majoritária, com apoio frágil, o sentido da lei dependeria de barganhas pontuais entre o executivo e o legislativo. (TOMIO, 2002 p. 11).

É nesse contexto que o processo de criação de municípios na Bahia entre 1989 e 1990 foi embargado. Desde a segunda metade dos anos 1980 que no estado da Bahia muitas lideranças políticas manifestaram o interesse em emancipar politicamente dezenas de distritos municipais. Muitos conseguiram, outros não. 
Tabela 4. Critérios para a criação de municípios, pela Lei Complementar Estadual de 1989 - comparação das condições apresentadas pelas localidades em avaliação.

\begin{tabular}{|c|c|c|c|c|c|c|c|}
\hline \multirow{2}{*}{$\begin{array}{l}\text { Distrito/ } \\
\text { Povoado/ } \\
\text { Município }\end{array}$} & \multicolumn{2}{|c|}{ Habitantes em $1991^{1}$} & \multirow{2}{*}{$\begin{array}{c}\text { Arrecadação } \\
\text { de impostos } \\
\text { estaduais nos dois } \\
\text { últimos exercícios }\end{array}$} & \multirow{2}{*}{$\begin{array}{l}\text { Atividade e } \\
\text { viabilidade } \\
\text { econômica }\end{array}$} & \multicolumn{2}{|c|}{$\begin{array}{l}\text { Eleitores na população total } \\
\text { em } 1^{1992^{2}}\end{array}$} & \multirow{2}{*}{$\begin{array}{l}\text { Edificações no } \\
\text { núcleo urbano/19913 } \\
\text { (mínimo de } 200 \\
\text { edificações) }\end{array}$} \\
\hline & $\begin{array}{c}\text { Urbana na sede } \\
\text { (mínimo de 1.000) }\end{array}$ & Total & & & Existente & $\begin{array}{l}\text { Estimado } \\
(20 \% \text { da } \\
\text { população) }\end{array}$ & \\
\hline Abrantes $^{4}$ & 6.197 & 13.984 & Não informada & Não informada & 4.973 & 2.797 & 5.738 \\
\hline Stela Dubois ${ }^{4}$ & 5.000 & 8.950 & Não informada & Não informada & 4.300 & 1.790 & 3.365 \\
\hline Apurema $^{5}$ & 1.959 & 7.649 & Não informada & Constatada & 2.800 & 1.530 & 464 \\
\hline Saubara $^{5}$ & 5.472 & 8.018 & Não informada & Constatada & 3.830 & 1.604 & 1.582 \\
\hline
\end{tabular}

Notas: 1. Dados do recenseamento geral do Brasil; 2. Considerou-se o número de eleitores nas eleições gerais de 1992; 3. Dados do recenseamento geral do Brasil; 4. Distrito não emancipado; 5. Distrito emancipado.

Fonte: Elaboração própria, com dados coletados em: Bahia, 1995; Brasil, 2010; 1991.

O fato é que na legislatura de 1987/90 na ALBA havia deputados simpáticos à criação de municípios, pois para além do interesse público, isso lhes era conveniente para a consolidação do futuro político, e tinha na presidência da casa seu maior defensor - o deputado Coriolano Sales, do PSB. O executivo baiano era ocupado por um governador que não se opunha à criação de municípios, Nilo Coelho, do PMDB.

Assim, em 1989 foi elaborada a LCE/02, publicada em 1990, por meio da qual foram criados de uma só vez 48 novos municípios. Acontece que nos outros distritos/povoados, 136 ao todo, havia problemas de conciliação de interesses entre as lideranças políticas locais e entre estes e o município de origem ${ }^{16}$. Com isso os processos estavam incompletos e foram incluídos no Ato das Disposições Transitórias da Constituição estadual de 1989 para posterior solução do que fosse possível. Ocorre que o novo governador eleito que tomou posse em março de 1991, Antonio Carlos Magalhães (ACM), era declaradamente contrário à criação de novos municípios.

ACM foi eleito numa coligação partidária junto com $51 \%$ dos deputados estaduais, número poderia crescer ainda mais com os parlamentares cooptáveis, ou seja, a ALBA estava em suas mãos.

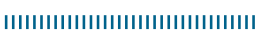

16 As pendência se referiam a: consulta plebiscitária a ser realizada pelo IBGE, levantamento das contas de arrecadação de tributos estaduais locais, delimitação de limites político-administrativos, até disputas políticas locais entre as lideranças envolvidas.
Nessas condições nenhum dos 136 processos de emancipação municipal teve encaminhamento.

Nesse rol de "áreas emancipáveis" estavam os distritos de Abrantes e Stela Dubois. Ambos tinham até mais condições de serem emancipados que os municípios de Apuarema e Saubara, criados em 1989. Abrantes não avançou em razão de uma disputa infrutífera e ingênua entre o executivo municipal e as lideranças de Abrantes, a qual envolvia limites político-administrativos inconciliáveis, que seria toda a parte litorânea do município de Camaçari e uma parte que englobava o pólo industrial de Camaçari com uma grande empresa - a Cetrel; fato que o prefeito de Camaçari à época não concordava.

A alegação das lideranças locais para a emancipação do distrito de Abrantes é o quase abandono da prefeitura de Camaçari, que não faz investimentos adequados no local. Atualmente o distrito foi redimensionado e possui área menor que a pleiteada em 1989 , com $230 \mathrm{~km}^{2}$, cerca de 50 mil habitantes (tabela 5), a economia local atende a uma parte considerável de veranistas e de residentes nesta parte da orla marítima, com muitos negócios no setor comercial, imobiliário e turístico, e mais recentemente, industrial.

O distrito de Stela Dubois está na lista dos "estoques de áreas emancipáveis" também com a alegação de negligência de investimentos da prefeitura de Jaguaquara. Este é também um distrito com grande potencial para ser emancipado, pois atendia a legislação da época. Contudo, 
Tabela 5. Condições atuais de municípios criados em 1989 e dos distritos que solicitaram emancipação em 1989.

\begin{tabular}{|c|c|c|c|c|c|c|c|c|}
\hline \multirow{3}{*}{$\begin{array}{l}\text { Distrito/ } \\
\text { Povoado/ } \\
\text { município }\end{array}$} & \multicolumn{4}{|c|}{ População } & \multirow{3}{*}{$\begin{array}{c}\text { Extensão } \\
(\mathbf{k m 2})\end{array}$} & \multirow{3}{*}{$\begin{array}{c}\text { Município- } \\
\text {-matriz }\end{array}$} & \multirow{3}{*}{$\begin{array}{c}\text { Eleitores } \\
\text { (1992) }\end{array}$} & \multirow{3}{*}{$\begin{array}{c}\text { Edificações no } \\
\text { núcleo urbano } \\
\text { (1991) }\end{array}$} \\
\hline & \multicolumn{2}{|c|}{1991} & \multicolumn{2}{|c|}{2010} & & & & \\
\hline & $\begin{array}{l}\text { Urbana } \\
\text { na sede }\end{array}$ & Total & Urbana & Total & & & & \\
\hline Abrantes & 6.197 & 13.984 & 23.547 & 48.283 & 230,00 & Camaçari & 4.973 & 5.738 \\
\hline Stela Dubois & 5.000 & 8.950 & 10.773 & 12.855 & 350,00 & Jaguaquara & 4.300 & 3.365 \\
\hline Apurema & 1.959 & 7.649 & 5.117 & 7.459 & 152,00 & Jaguaquara & 2.800 & 464 \\
\hline Saubara & 5.472 & 8.018 & 7.584 & 11.201 & 158,00 & Santo Amaro & 3.830 & 1.582 \\
\hline
\end{tabular}

Fonte: Elaboração própria, com dados coletados em: Brasil, 2010; 1991.

disputas políticas entre as lideranças locais para apresentar-se como o idealizador e defensor da ideia, não conseguiu a emancipação (SOUZA, R., 2015). Após as mobilizações pela emancipação serem acalmadas, o distrito teve seus limites políticos-administrativos redefinidos e passou a ter melhor atenção da prefeitura de Jaguaquara.

Atualmente ambos os distritos possuem condições de atender até a nova lei aprovada em 2015 no Senado Federal que prevê uma população na área que pretende ser emancipada não mais de 8.000 habitantes, mas agora de 12.000 na região Nordeste.

\section{Conclusão}

do exposto até aqui, pode-se concluir que ainda não se sabe tudo sobre as reais implicações da criação de novos municípios no Brasil. A criação de municípios quando é noticiada pela imprensa, quase sempre traz explicito um conteúdo,pelo menos moralista, veiculando a ideia sempre negativa e conservadora a respeito deste fato, como sendo mais uma fonte de subtração dos recursos públicos, os quais se sabem que são escassos e muito caros à sociedade nacional como um todo.

Este tipo de crítica, obtusa por excelência, inclusive por força da tradição questionável das ações de improbidade praticadas pela maior parte dos agentes públicos e dos políticos brasileiros em geral, não acrescenta nada de novo à compreensão e possibilidade de superação dos óbices ao atendimento das demandas dos milhares de cidadãos em seus lugares de vivência cotidiana, os distritos municipais, negligenciados pelas administrações públicas locais que lhes negam a possibilidade de usufruto dos benefícios criados pela própria sociedade humana em seu devir.

Os autores desse tipo de crítica desconhecem a noção de federação e o conceito de descentralização política, com as devidas competências, responsabilidades e fontes de recursos para provimento das demandas requeridas pelos cidadãos. Desconhecem que para a federação funcionar a contento sob o signo da equidade de direitos e responsabilidades é necessário que nos processos coordenação do federalismo haja mais cooperação que de concorrência. Que neste caso, a concorrência sem constrangimentos entre os entes federados conduz à fragilização do pacto federativo, especialmente quando os sujeitos que operam o sistema da União Federal, voluntariamente tentam transformar os entes federados subnacionais mais vulneráveis (estados pobres e ou fracos politicamente, e municípios pouco influentes) em "pária do federalismo", criando uma escassez de recursos intencionalmente, como é o caso de limitar a partilha dos tributos voltados ao FPM e ao FPE, enquanto que a União Federal fica com mais de $80 \%$ dos recursos arrecadados por serem em sua maior parte contribuições, e não tributos.

É baseado também neste tipo de equívoco que os técnicos e acadêmicos elaboram planilhas de cálculos contábeis e diante de resultados "inequívocos" concluem que a criação de municípios pequenos e pouco populosos e momentaneamente sem viabilidade econômica são ineficientes e atrapalham o desempenho dos municípios maiores, em razão de não terem condições técnicas e nem políticas para dar conta 
de um regime fiscal austero. Para eles, por conta de tudo isso estes novos municípios são inviáveis, tornando-se cronicamente dependentes dos recursos de transferência intergovernamentais.

Com isso, a "proliferação" de pequenos municípios constitui irracionalidade administrativa e fiscal, pois contribui para criar óbices ao desenvolvimento de municípios economicamente mais dinâmicos e administrativamente melhor organizados.

$\mathrm{O}$ argumento essencial dos autores que defendem esses pontos de vista baseia-se em princípios eminentemente fiscais, não nas pessoas e nas possibilidades de transformações ensejadas pelo próprio devir, não no que os cidadãos em sua vida simples esperam do Estado, e que agradeceriam se pudessem ver atendidas suas demandas frequentes e inadiáveis: acesso mais fácil à infraestrutura pública, bens e serviços, de preferência o mais perto possível de seus locais habituais de trabalho, de lazer e de habitação.

Mas a razão fundamentalmente econômica implica reduzir a comunidade urbana a algo próximo das economias de aglomeração. Esses críticos não desconfiam que para compreender o fenômeno das emancipações de distritos e a posterior criação de municípios em sua inteireza devem estender a vista e a análise sobre o fato primordial, gerador da dependência econômica dos municípios em relação às transferências intergovernamentais, que é a confusão intencional estabelecida na coordenação do próprio pacto federativo, quando não prescreve claramente competências, responsabilidades e recursos adequados para os distintos entes federados, sem concorrência ou sobreposição de ações.

Entretanto, concorda-se que a descentralização política do Estado no Brasil, sobretudo com a promulgação da Constituição federal de 1988, criou mais expectativa que ato realizador. Deve-se ter em mente que os parlamentares constituintes à época da elaboração da referida constituição se empenharam em deixar claro o preceito descentralizador e autonomista, inclusive reconhecendo as instâncias subnacionais de governo como ente federado. Por outro lado, também criaram e aperfeiçoaram mecanismos que assegurassem à elite política e econômica nacional o controle sobre esta descentralização, em vez de prescrever fortemente a cooperação e dotar a União Federal e os Estados membros de instrumentos de coordenação da vida nacional, no sentido de favorecer o melhor desempenho possível dos municípios quanto ao atendimento das demandas dos cidadãos em sua base espacial de vivência cotidiana.

Por fim, quanto à dimensão operacional do processo de criação de municípios acredita-se que há mais subjetividade que o critério da lei. E os distritos de Abrantes e Stela Dubois, bem como uma parte dos demais que tiveram o processo de emancipação política requerida, não foram emancipados com os demais que tiveram seus pleitos aprovados por falta de unidade na representação política e clareza no objeto de interesse identificado na prestação de serviços aos cidadãos o mais perto possível.

Alinha dura adotada pelo governador do estado na época frontalmente contra a criação de municípios, independente de seu benefício à população local semiabandonada em seus distritos esquecidos pelo governo municipal inviabilizou a emancipação de distritos, inclusive os emancipáveis. Já no caso do distrito de Apuarema e Saubara, emancipado no processo precedente, além da força dos deputados, na época, que o favoreceu, houve também a flexibilidade do executivo estadual anterior, o qual era favorável.

\section{Referências}

ABRUCIO, Fernando Luiz. Para além da descentralização: os desafios da coordenação federativa no Brasil. In: FLEURY, Sonia. Democracia, descentralização e desenvolvimento: Brasil e Espanha. Rio de Janeiro: FGV, 2006. p. 77-126

ALMEIDA, Kátia Rocha. Emancipação municipal e transformações socioespaciais: os casos de Bom Jesus da Serra e Caetanos. 2013. 235f. Dissertação (Programa de Pós-Graduação em Geografia) - Instituto de Geociências, UFBA, Salvador, 2013.

ALMEIDA, Maria Hermínia Tavares de. Revista de Sociologia Política, Curitiba, n. 24, p. 29-40, jun., 2005.

BAHIA. Constituição do Estado da Bahia. Disponível em: <http://www.al.ba.gov.br/PublitaoPHP/ 
Uploads/17072014091825000000_Constituicao_ Estadual_03022016_EC22.pdf>. Acesso em: 20 jul. 2016.

BAHIA. Lei Complementar No 002 de 04 de maio de 1990. Estabelece os requisitos para criação de Municípios e Distritos, e dá outras providências. Disponível em: <http://www.legislabahia.ba.gov.br/>. Acesso em: 20 mar. 2012.

BRASIL. Instituto Brasileiro de Geografia e Estatística. Sinopse do censo demográfico da Bahia, 2010. Disponível em: <http://www.censo2010.ibge.gov.br/sinopse/index. php?uf=29\&dados=0 >. Acesso em: 20 fev. 2017a.

BRASIL. Aprovadas regras para criação e fusão de municípios. Disponível em: <http://www12.senado.leg.br/noticias/ materias/2015/07/15/aprovadas-regras-para-criacao-efusao-de-municipios>. Acesso em: 8 mar. 2017b.

BRASIL. DRU. Disponível em: <http://www12.senado.leg. $\mathrm{br} /$ noticias/entenda-o-assunto/dru $\rangle$. Acesso em 20 mar. 2016a

BRASIL.Emenda Constitucional $N^{\circ} 15$, de 1996. Disponível em: <http://www2.camara.leg.br/legin/fed/emecon/1996/ emendaconstitucional-15-12-setembro-1996-369745publicacaooriginal-1-pl.html >Acesso em 25 mar. 2016b

BRASIL. Tesouro Nacional. Resultado Primário do Governo Central. Disponível em: <http://www.tesouro.fazenda. gov.br/pt/web/stn/resultado-do-tesouro-nacional>. Acesso em: 4 fev. 2016c.

BRASIL. Constituição da República Federativa do Brasil de 1988. Disponível em: <https://www.planalto.gov.br/ ccivil_03/constituicao/constituicao.htm>. Acesso em 20 jun. 2016.

BRASIL. Emenda Constitucional No 14, de 12 de Setembro de 1996. Modifica os Arts. 34, 208, 211 e 212 da Constituição Federal e dá nova redação ao Art. 60 do Ato das Disposições Constitucionais Transitórias. Disponível em: <http://www.planalto.gov.br/ ccivil_03/ constituicao/Emendas/Emc/ emc14.htm>. Acesso em 4 fev. 2015a.

BRASIL.Emenda Constitucional $n^{\circ}$ 5, de 1961.Institui novas discriminações de renda em favor dos municípios brasileiros. Disponível em: <http://www2.camara.leg.br/legin/ fed/emecon/1960-1969/emendaconstitucional-5-21novembro-1961-363625-publicacaooriginal-1-pl.html>. Acesso em: 20 mar. 2015b.

BRASIL. Instituto Brasileiro de Geografia e Estatística. Evolução da divisão territorial do Brasil - 1872-2010. Rio de Janeiro: IBGE, 2011.

BRASIL. Instituto Brasileiro de Geografia e Estatística. Sinopse preliminar do censo demográfico da Bahia, 1991. Rio de Janeiro: IBGE, 1991.

BRASIL. Lei Complementar n ${ }^{\circ} 1$, de 9 de Novembro de 1967. Estabelece os requisitos mínimos de população e renda pública e a forma de consulta prévia às populações locais para a criação de novos municípios, e dá outras providências. (Redação dada pela LCP n ${ }^{\circ} 46$, de 21.8.1984). Disponível em: <http://www.planalto.gov.br/ccivil_03/ leis/lcp/ Lcp01.htm>. Acesso em 28 mar. 2015c.
BRASILEIRO, Ana Maria. O município como sistema político. Rio de Janeiro: FGV, 1973. 124p.

BREMAEKER, François E. J. Despesas dos municípios do estado da Bahia com serviços, ações e programas de competência dos estados e da União em 2011. Salvador: Associação de Transparência Municipal, 2013. 52f. (Estudo Técnico $\mathrm{n}^{\circ}$ 241)

BREMAEKER, François E. J.. Os novos municípios: surgimento, problemas e soluções. Revista de Administração Municipal, Rio de Janeiro, v. 40, n. 206, jan./mar., p. 88-99, 1993.

BREMAEKER, François E. J. Os novos municípios brasileiros. Revista de Administração Municipal, Rio de Janeiro, v. 38, n. 200, jul./set., p. 82-91, 1991.

BRITO, Cristovão; RAMOS, Ana Paula Santana Rigaud. População, segregação socioespacial e turismo em Bom Jesus dos Pobres (Saubara-Ba). Disponível em:<http://www. ivsinarub.ufba.br/>. Acesso em 20 mar. 2017.

BRITO, Cristovão.Do espaço ao território: a grande fábrica de calçados e o sindicato dos trabalhadores calçadistas em Ipirá-BA. In: FONSECA, Antônio Angelo Martins; Brito, Cristovão; LEDA, Renato Leone Miranda (Orgs.). Dinâmica da reestruturação do espaço local e regional no estado da Bahia. 1. ed. Salvador: JM Gráfica e Editora, 2010. p. 157-180.

BRITO, Cristovão. A Petrobras e a gestão do território no Recôncavo baiano. 2004. 316f. Tese (Programa de PósGraduação em Geografia) - Centro de Filosofia e Ciências Humanas, UFSC, Florianópolis, 2004.

CASTRO, Antônio Barros de. 7 ensaios sobre a economia brasileira. 2. ed., v. 2. Rio de Janeiro: Forense Universitária, 1975. 248p

CIGOLINI, Adilar Antônio. A fragmentação do território em unidades político-administrativas: análise da criação de municípios no estado do Paraná. 1999. 106f. Dissertação (Programa de Pós-Graduação em Geografia) - Centro de Filosofia e Ciências Humanas, UFSC, Florianópolis, 1999.

CPDOC. Assembleia Nacional Constituinte de 1987-88. Disponível em: <http://www.fgv.br/cpdoc/acervo/ dicionarios/verbete-tematico/assembleia-nacionalconstituinte-de-1987-88>. Acesso em 22 fev. 2017.

DULCI, Otávio Soares. Guerra fiscal, desenvolvimento desigual e relações federativas no Brasil. Revista de Sociologia e Política, n. 18, p. 95-107, jun. 2002.

FAHEL, Murilo; TELES, Letícia; CAMINHAS, Davy. Pobreza multidimensional no Brasil: uma análise de sua incidência, intensidade e índice. Research Gate. 27 f. Disponível em: <https://www.researchgate.net/ publication/281866079>. Acesso em 01 abr. 2017.

FONSECA, Antônio Angelo Martins. Instituição e desenvolvimento territorial: o desempenho municipal após a descentralização. Feira de Santana: Editora da UEFS, 2006. 353p

FURTADO, Celso. O mito do desenvolvimento econômico. 5. ed. Rio de Janeiro: Paz e Terra, 1981. 117p 
GOMES, Gustavo Maia; MAC DOWELL, Maria Cristina. Descentralização política, federalismo fiscal e criação de municípios: o que é mau para o econômico nem sempre é bom para o social. Texto Para Discussão, Brasília, n. 706, p. 1-27, 2000.

JACINT, Jordana. As comunidades autônomas e a política de descentralização na Espanha democrática. In: FLEURY, Sonia. Democracia, descentralização e desenvolvimento: Brasil e Espanha. Rio de Janeiro: FGV, 2006. p. 213-238

MELLO, Diogo Lordello de. O município na organização nacional: bases para uma reforma do regime municipal brasileiro. Rio de Janeiro: IBAM, 1971. 87p.

NERY, Maria Gorethe Silva. As implicações socioespaciais da instalação da indústria de calçados na Bahia, Minas Gerais e Santa Catarina. 2016. 320f. Tese (Programa de PósGraduação em Geografia) - Instituto de Geociências, UFBA, Salvador, 2016.

NORONHA, Ruldof. Emancipação municipal: implicações espaciais da divisão político-administrativa do território fluminense. 1997. 132f. Dissertação (Programa de PósGraduação em Geografia) - Centro de Ciências Naturais e Matemática, UFRJ, Rio de Janeiro, 1997.

OLIVEIRA, Ildo Rodrigues. Indústria de calçados e implicações socioespaciais: a grande fábrica de calçados no município de Santo Estevão-BA. 2012. 150f. Dissertação (Programa de Pós-Graduação em Geografia) - Instituto de Geociências, UFBA, Salvador, 2012.

OLIVEIRA, Maria Dalva Carneiro de. Implicações espaciais do processo de emancipação política no município de Riachão do Jacuípe-Ba. 2009. 191f. Dissertação (Programa de Pós-Graduação em Geografia) - Instituto de Geociências, UFBA, Salvador, 2009.

RAMIÓ, Carles; SALVADOR, Miquel. O processo de descentralização regional na Espanha e as dificuldades para inovação institucional das novas administrações públicas. In: FLEURY, Sonia. Democracia, descentralização e desenvolvimento: Brasil e Espanha. Rio de Janeiro: FGV, 2006. p. 239-265

ROSTOVTZEFF, Michael Ivanovich. Roma: de los orígenes a la última crisis. Traducão de Tula Núñez de Latorre, 4. ed. Buenos Aires: EUDEBA, 1977. 179p.

SCHEINOWITZ, A. S. A descentralização do Estado: Bélgica, França, Itália Espanha, Portugal, Dinamarca, Brasil, Estados Unidos. Brasília: Brasil Jurídica, 1993. 414p

SEN, Amartya Kumar. Desenvolvimento com liberdade. Tradução de Laura Teixeira Motta. São Paulo: Companhia das Letras, 2000. 409p. Título original: Development as freedom.

SILVA, Sylvio Bandeira de Mello e; SILVA, Barbara-Christine Nentwig; COELHO, Araori Silva. Desequilíbrios e desigualdades regionais no Brasil e nos estados brasileiros. João Pessoa: Grafset, 2008. 128p.

SMITH, Neil. Desenvolvimento desigual: natureza, capital e a produção do espaço. Tradução de Eduardo de Almeida Navarro. São Paulo: Bertrand Brasil, 1988. 250p. Título original: Unevendevelopment.

SOUZA, Marcelo José Lopes de. Mudar a cidade: uma introdução crítica ao planejamento e à gestão urbanos. 3. ed. Rio de Janeiro: Bartrand Brasil, 2004. 556p

TOMIO, Fabrício Ricardo de Limas. Federalismo, municípios e decisões legislativas: a criação de municípios no Rio Grande do Sul. Revista de Sociologia e Política. Curitiba, 24, p. 123-148, jun., 2005.

TOMIO, Fabrício Ricardo de Lima. A criação de municípios após a constituição de 1988. Revista Brasileira de Ciências Sociais. São Paulo, v. 17, n. 48, p. 61- 89, 2002.

TROTSKI, Leon. A história da revolução Russa. Tradução de E. Huggins. Rio de Janeiro: Saga, 1967. v.1.

VARSANO, Ricardo. A guerra fiscal do icms: quem ganha e quem perde. Planejamento e Políticas Públicas, n. 15, p. 3-18, Jun., 1997.

\section{Cristovão Brito}

Possui graduação em Geografia pela Universidade Federal da Bahia (1993), mestrado em Geografia pela Universidade Federal da Bahia (1997) e doutorado em Geografia pela Universidade Federal de Santa Catarina (2004). Atualmente é professor Associado do Departamento de Geografia da Universidade Federal da Bahia e professor permanente do Programa de Pós-Graduação em Geografia da UFBA. Tem experiência na área de Geografia, com ênfase em Geografia Urbana, Geografia Regional, Geografia Política, Geografia Econômica, atuando principalmente nos seguintes temas: agentes sociais, cidade, redes geográficas, desenvolvimento regional, desenvolvimento local e poder. E-mail: catbri35@yahoo.com.br

\section{Romilda Assunção Souza}

Possui o curso de Magistério e graduação em Geografia pela Universidade Estadual do Sudoeste da Bahia (2005). É Especialista em Antropologia com Ênfase em Cultura Afro-brasileira pela Universidade Estadual do Sudoeste da Bahia (2008). Mestre em Geografia Política pela Universidade Federal da Bahia.Tem experiência na área de Geografia, com Ênfase em Desenvolvimento Territorial e Regional. Atualmente desenvolve pesquisa na área de Geografia Política, enfocando a emancipação de distritos como possibilidade de descentralização e autonomia local. E-mail: lala3019@hotmail.com 